\title{
Services in the European Single Market and in World Trade: Country Implementation Barriers
}

\author{
John Mylonakis \\ Athens, Greece
}

\begin{abstract}
Received: Dec. 29, 2021 Accepted: Jan. 30, 2022 Online published: Feb. 17, 2022
doi:10.5296/jpag.v12i1.19561ＵRL: https://doi.org/10.5296/jpag.v12i1.19561
\end{abstract}

\begin{abstract}
The Services sector has been the backbone of the global economy and the most dynamic player in international trade. Trade in Services helps to develop countries' economies, increases competition, and promotes the personal skills of employees. The European Single Market is a cornerstone of the European Union, being the single space within which economic growth factors move freely and unhindered. The scope of this paper is to connect these social and economic factors and to show on the one hand the expected benefits from a single market and on the other the chaotic difficulties emerging from its implementation in many member countries. The Covid-19 pandemic highlighted weaknesses in the functioning of the European Single Market. It is worth mentioning the fact that the Services Directive is the most important step towards achieving a Single Market as it ensures that both service providers and recipients of services can more easily benefit from fundamental freedoms of the European Union, such as freedom of establishment and freedom to provide services to cross-border level.
\end{abstract}

Keywords: services, trade in services, European single market, services directive

\section{Introduction}

The term Service usually describes a series of actions, which are aimed at satisfying the needs and desires of consumers (Grönroos, 1990) and which are carried out between the provider (person, company, organization) and the buyer of the service (consumer). In all international service management and marketing manuals, Services have been analyzed and developed, since the 1980s, as a separate sector from that of the production and distribution of goods, based on their characteristics (Zeithaml, 1988; Parasuraman, Zeithaml \& Berry, 1988).

The characteristics of the Services are described as Intangibility, customer participation, the simultaneous production and consumption of the offered service (simultaneity), the immediate depreciation or consumption of the purchased service (perishability), the heterogeneity of buyers and non-transferable ownership of the Services. On these 
characteristics of the Services, as a distinct sector of the economy of each country, have been based and defined all the policies, legislation and legal order of both governments and the World and International Organizations (Garabiol-Furet, 2006).

Today, all forms of Services have been internationalized, whether they are autonomous (financial, accounting, tax) or attached to certain goods (consumer products). The Services sector has become the most dynamic element of world trade (WTO, 2019; OECD, 2009). In 2019 (before the start of the pandemic), global services exports were valued at US \$ 6.1 trillion, representing 7\% of world GDP (UNCTAD, 2020). Also, in 2019 in more than half of the world's economies, the percentage of Services in GDP was greater than $10 \%$. In many economies in Europe, the Caribbean and Southeast Asia, exports of the Services sector accounted for a particularly large share of their GDP. In some European economies, such as Luxembourg, Malta, and Ireland, as well as in several island economies, Services exports exceeded $70 \%$ of their GDP (UNCTAD, 2020). In Greece, the Services sector is particularly important for the economy, participating in 2019 by $2 / 3$ of the country's GDP.

In Greece, Law no. 3844/2010 (Government Gazette 63/63 / 3-5-2010) adapts the Greek legislation to the provisions of Directive 2006 / EC of the European Parliament and of the Council of 12 December 2006 on Services in the Internal Market. It establishes general provisions that facilitate the exercise of the freedom of establishment of service providers and the freedom to provide services, while maintaining a high-quality level of services. The law applies to the Services of providers established in a Member State of the European Union '(Article 4), in compliance with the rules of the Lisbon Treaties governing the right of establishment and the free movement of services (par. 3, art. 5).

\section{World Trade in Services}

Services are the fastest growing sector in the global economy as trade in Services and Foreign Direct Investment in them has increased in recent decades at a faster rate compared to trade in goods (Ghani \& Kharas, 2010). In Developed and Most Developing Countries the share of Services in GDP now exceeds 80 to $85 \%$. Services today are distinguished by complexity as they are now mixed with the production of goods, trade, and consumption (Cambridge University Press, 2014). Their degree of participation in each of these areas has not been clearly and precisely investigated (Low, 2016). An ever-increasing number of industrial companies worldwide buy, produce, and sell services, hire Service people, whose services they market (servicification).

The Service sectors were greatly affected by the COVID-19 pandemic. Tourism, transport, and distribution services, in 2019 and 2020 decreased significantly by almost 20\%, because of mobility restrictions and social distance measures imposed worldwide to address the pandemic (WTO, 2020).

The decline in trade in goods resulting from the economic slowdown has helped to reduce trade in related services, such as international maritime freight. Finally, the increased use of online services during the COVID-19 pandemic highlighted the strong differences in technological infrastructure and connectivity in many countries. Online courses are not 
available for students without computers and teleworking is not an option for employees without a broadband connection.

\section{Development of World Trade in Services}

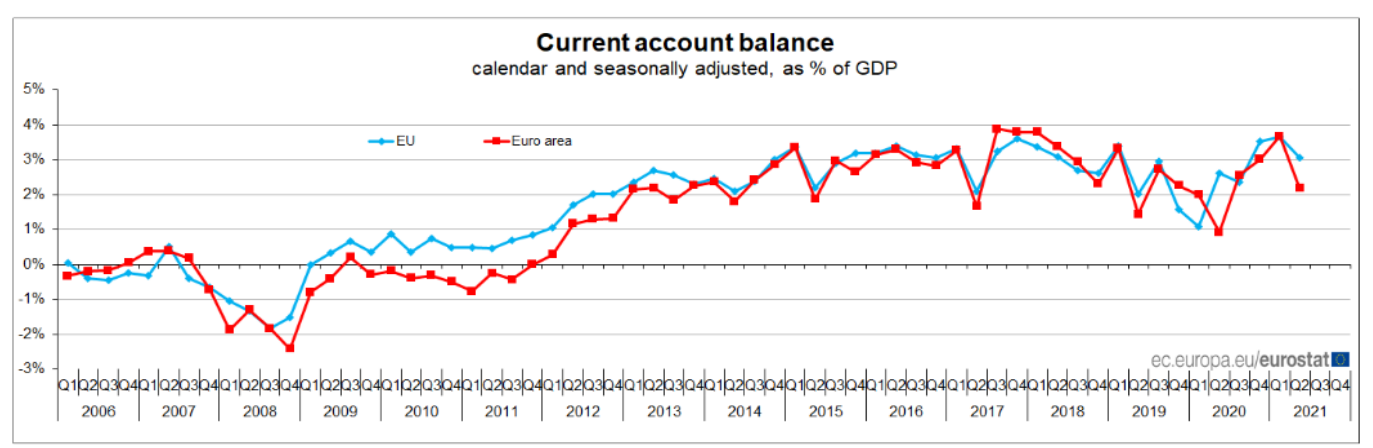

Source: Eurostat (Oct. 2021), International Trade in Services

In 2019, global exports of services were valued at US \$ 6.1 trillion, representing 7\% of world GDP (UNCTAD, 2020). EU Services exports to the rest of the world increased by $0.7 \%$ between 2017 and 2018, from $€ 912.4$ billion to $€ 918.5$ billion, while imports increased by $1.1 \%$, from $€ 720.7$ billion to EUR 728.4 billion (Eurostat 2021). After a modest increase of $1.9 \%$ in 2019, global exports of services fell sharply in the first two quarters of 2020, due to the onset of the COVID-19 pandemic, with recovery points in the third quarter of 2020 . Nevertheless, the decline continues by $19.9 \%$ on an annual basis for the third quarter of 2020 (UNCTAD, 2020).

The development of World Trade in Services is neither self-evident, nor automatic, nor certain, but also without obstacles. It is carried out through voluntary coalitions of states, at bilateral, pluralistic and/or multilateral level, following tough and long-term negotiations between well-read players and with divergent, often, economic, and commercial interests.

At the World Trade Organization (WTO), negotiations on the liberalization of Trade in Services have been extremely important in recent years. From July 2008 until today, the Member States participating in the WTO Trade Services Committee have sought to make up for lost ground on a multilateral level, despite still falling short of the objectives of a new General Agreement on Trade in Services (GATS).

Efforts to close a new Global Compact on Services continue to stumble on the Less Developed and Developing Countries' refusal to limit their various protectionist and free market access policies, which restrict economic development and make global trade difficult, if not impossible (Gao, 2018). In recent years, the WTO has been sailing between devaluation and annihilation, despite the recent election of a new Director General and his staff, as well as the commitment of the leaders of the world's most powerful countries (G7, G20) to keep him alive.

Under the World Trade Organization (WTO), Trade in Services is covered by the General Services Trade Agreement (GATS) and includes Business Action Services, Financial and Insurance Services, Telecommunications, Education, Electronic and Commercial Services. 


\section{Macrothink}

Journal of Public Administration and Governance

ISSN 2161-7104

2022, Vol. 12, No. 1

Transportation Services, Architecture and Engineering Services as well as Environmental and Tourism Services (Adlung \& Mamdouh, 2013).

It also includes the provision of all categories of services at the cross-border level (mode 1), use (consumption) of services abroad (mode 2), direct investments for the provision of commercial services (mode 3) and physical presence of employees abroad (mode 4). To the above classic categorization of Services was added a new very important category of Services (Antimiani \& Cernat, 2018; Cernat, 2017; Foltea 2017), which concerns the whole range of Services that are integrated in the productive chain of goods (technology, design, energy) and are part of the exported final industrial goods (mode 5). In this way the connection of the Trade of consumer products (goods) with that of the Trade of Services is directly connected (Nordwall, 2016).

\section{Services by category}

EU-27 exports of services to non-member countries, 2017

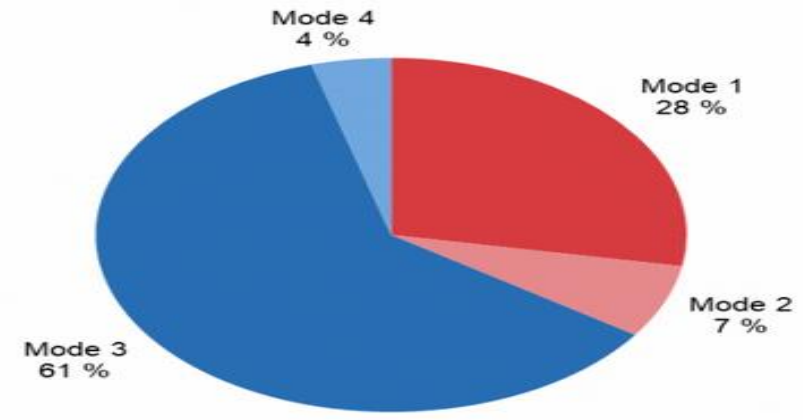

Note: Estimates using the simplified Eurostat model. Modes

1,2 and $4:$ ITSS exports, adjusted by excluding goods

and including distribution services from trade in goods
statistics. Mode 3: outward FATS data.

eurostat

EU-27 exports of services to non-member countries broken down by mode of supply, 2017

Source: Eurostat (2017)

As a result of the COVID-19 pandemic, Trade in Services of certain categories of Services has had a serious impact. Services that involve proximity between suppliers and consumers have been severely affected. Services requiring the movement of consumers abroad (mode 2) and Services requiring the temporary cross-border movement of individuals (mode 4) are paralyzed, such as Tourism and travel destinations. The pandemic, also, negatively affected the provision of services through commercial presences (mode 4), due to its impact on existing market operations abroad and the consequently negative impact on business decisions to start new companies (WTO, 2020).

\section{European Single Market}

The European Single Market is a cornerstone of the European Union, being the single space within which economic growth factors (People, Goods, Services and Capital) move freely 
and unhindered. A fully functioning Single Market allows the citizens of the European Union to enjoy a wider choice of supply and consumption of Services and Goods as well as better employment opportunities.

Equally important, however, are the benefits of the Single Market for companies and Organizations that operate or wish to develop cross-border activity (Bublitz, 2018). Mainly due to delayed or incomplete integration and implementation of European legislation in the national legal order, the Single Market has not yet been fully completed, especially in areas such as Services, the Digital Single Market and the mobility of citizens and workers. Also, the network industries (Energy, Freight, Telecommunications, Post), are either excluded from the Single Market applications, or operate with controversial results for the benefit of the European consumer (Erixon \& Georgieva, 2016).

To make full use of the possibilities of cross-border activities (free movement of economic growth factors) and to refer to a substantially Single, well-functioning European Market and fully competitive in international economic and trade developments, it is necessary to ensure its economic, social and adaptability. policy, climate, and health changes in recent years (OECD, 2020). The needs of the European economy are evolving and diversifying rapidly, calling for actions to move towards green growth and digital transformation as well as easier movement of human resources across borders. At the same time, the Covid-19 pandemic highlighted weaknesses in the functioning of the European Single Market, such as the free movement of Services and Goods. At the same time, however, it provided incentives for targeted actions by the European Union institutions to ensure the resilience and adaptability of the Single Market to current and future challenges.

The aim of the Member States of the European Union is to support initiatives to restore, further deepen and strengthen the Single Market, but also to ensure the resilience and continuity of its policies. To this end, the European Commission has repeatedly called on the Member States of the Union to assume their respective roles, citing co-responsibility (Szczepanski, 2013). Relevant is the recent call for acceleration of the planned new Single Market Emergency Instrument (SMEI), which will operate in crisis situations. To this end, it was proposed in 2019 by the European Commission to include in the Annual Report on the Single Market a relevant performance scoreboard (Single Market Scoreboard), which is currently postponed to next year.

It also proposes the development of the Single Market Enforcement Task Force (SMET) Initiatives for the implementation of the rules of the Single Market and emphasizes the need to promote the participation of the representatives of the Member States in the relevant meetings to ensure access to the fullest information in order to form functional national positions.

The experience gained so far leads to the view that the key issues to be addressed by the Single Market, and consequently the European economy, are related to a better understanding of the current and future strategic dependencies of the European Union. They are also linked to the development of informed, proportionate, and targeted policy measures, both in terms of the recovery of the European economy and the return to the pre-Covid-19 situation, but also 
in terms of ensuring the resilience and adaptability of the Single Market to future challenges. Many legislative and other initiatives of the European Commission are moving in this direction, with the aim of creating appropriate new tools, but also for the utilization of already existing financial (and non-financial) tools, such as the program NextGenerationEU.

\section{The European Services Directive}

Despite significant progress in completing the European Union Trade in Services in recent decades, cross-border trade in the Member States of the European Union lags that in the United States (Barnard, 2008). The Directive on Services in the European Internal Market (123/2006) was issued on 12 December 2006, entered into force on 28 December 2009. It was incorporated into the Greek legal order in 2010 by Law 3844/2201 (Government Gazette A'63/3-5-2010). The goal of this basic Directive is to create a genuine European Internal Market for Services. Through the opportunities provided, businesses and consumers will be able to freely produce, market and make full use of the opportunities and quality provided by the Services sector in all Member States of the European Union (Corugedo \& Pérez 2014; Delgado (2006).

The Services Directive is an important step forward as it ensures that both providers and recipients of services can more easily take advantage of the fundamental opportunities guaranteed by Articles 43 and 49 of the Treaty on European Union (freedom of establishment and freedom to provide services at the cross-border level). To this end, the provisions of this Directive are intended to simplify administrative procedures, remove barriers to the provision of services and to strengthen both mutual trust between Member States and the trust of providers and consumers in the European Union Internal Market. For this reason, the Directive applies in many areas of the provision of Services, while Member States are called upon to take additional legislative measures to meet these conditions (Feijóo, 2019; Schrijvershof \& van de Hel, 2019).

The Treaty on European Union, as well as the case law of the Court of Justice of the European Union, have contributed to the delimitation of the concept of 'Service', as any self-employed economic activity that is normally provided for remuneration (par. 1, art. 4). As stated, this Directive establishes a general framework for the Services sector, considering the specific characteristics of each type of activity or profession, applies only to requirements affecting access to or pursuit of Services and includes a which are constantly changing.

Regarding the scope of application of the Services Directive, the basic rule is that it applies to every sector and type of Service offer, which is not specifically excluded from its scope (par. 2, art. 2). These include non-financial services of general interest (public transport, postal services, healthcare).

All the service sectors excluded from the Services Directive have been examined and addressed over time in the institutions of the European Union, with the adoption of a series of individual, specialized Directives. Consultations for the issuance of new Guidelines or updates of old ones in various areas of the Services are ongoing, at all levels of negotiation of Working Groups, National Experts and Technical Advisers (Chang, 2010). 
Regarding the providers covered, it should be noted that the Services Directive applies to services provided by a natural person who is a national of a Member State or by a legal entity established in a Member State, while covering the requirements affecting access to a service activity. Services or its exercise. The concept of requirement covers any obligation, prohibition, condition, or other limit imposed on Service Providers or recipients of Services (par. 7, art. 4), such as the obligation to obtain a license or submit a statement to the competent authorities.

Then, with Article 10 (Conditions for granting a license) the conditions for granting a license are set. Paragraph 2, also, stipulates that the conditions for granting a license must be clear and unquestionable, objective, transparent and accessible and have been made public in advance to ensure the fair and impartial treatment of all companies and the evaluation of applications based on their characteristics, accessibility, and publicity ensure that the licensing system is understood by all applicants and that the various stages of the process are known in advance.

The Article 14 (Prohibited Requirements) contains a long list of requirements that Member States may not impose on access to or pursuit of a Service activity, such as:

Prohibition of claims based, directly or indirectly, on nationality or, in the case of companies, their place of residence.

$>$ Prohibition of requirements restricting the establishment of Service Providers in a Member State as well as requirements prohibiting Service Providers from registering or registering with professional bodies or associations in more than one Member State.

Prohibition of requirements that restrict the freedom of choice of the Service Provider, regarding the main or secondary installation.

Prohibition of reciprocity conditions.

Prohibition of financial trials as they significantly delay the installation of Service Providers and they do not completely prevent the installation of new entrants.

Prohibition of the involvement of competing bodies in the decisions of the competent authorities.

Prohibition of the obligation to obtain additional financial guarantees or to conclude an insurance contract with an institution established in the same Member State.

Prohibition of the obligation to register in advance or to carry on the activity for a certain period in the same Member State.

Subsequently, Article 15 (Requirements to be assessed) sets out the requirements, which must be assessed as they constitute serious obstacles to freedom of establishment and can often be replaced by less restrictive measures. In this context, Member States are invited to examine whether each of the requirements of its legislation identified is non-discriminatory, justified by an overriding reason in the public interest and is proportionate. Pursuant to paragraph 2 of the same article, Member States are required to consider whether their legal systems make access to or pursuit of a service activity subject to compliance with the following 
non-discriminatory requirements, such as:

$\checkmark$ Quantitative or territorial constraints.

$\checkmark$ Obligation of the Service Provider to take a specific legal form.

$\checkmark$ Requirements regarding the holding of company capital.

$\checkmark$ Requirements that restrict the provision of certain Services to specific providers.

$\checkmark$ Prohibition of the establishment of more than one establishment in the territory of the same Member State.

$\checkmark$ Obligations to employ a minimum number of employees.

$\checkmark$ Obligations to apply set minimum or maximum prices.

$\checkmark$ Requirement for providers to offer, together with their own service, other specific types of Services.

Regarding the importance of cross-border provision of Services, this is provided in Articles 16 and 17 of the Services Directive. An establishment is defined as the actual pursuit of an economic activity, through a fixed physical establishment, for an indefinite period in a Member State. The Article 16 (Free provision of Services) provides for the free provision of cross-border Services without unjustified restrictions. In fact, it is one of the cornerstones of the Services Directive and applies to all services that fall within its scope, except for the Services or issues listed in Article 17. Also, paragraph 2 of art. 16 mentions requirements that in principle cannot be imposed by a Member State in the case of provision of Services in its territory by a provider established in another Member State. It also refers to requirements that normally cannot be imposed on recipients of Services.

Article 20 (Non-discrimination) establishes the general obligation of Member States and service providers not to discriminate. In doing so, Member States are required to ensure that recipients of the Services are not subject to discriminatory requirements based on their nationality or place of residence. Next, Article 21 (Assistance to Recipients) examines the strengthening of the trust of the accepted Services, by providing them with the right means, so that they can make informed choices and comparisons when making cross-border transactions.

\section{Implementation of Services Directive with Obstacles}

At this point it should be noted that the Services Directive (123/2006) has been based on many European laws and proposals of National Authorities and Regulations. Others have been adopted, such as Regulation 2018/302 on tackling unjustified geographical exclusion and other forms of discrimination based on the nationality, place of residence or place of establishment of customers within the Internal Market (Kox \& Lejour, 2006). Other proposals remained mere proposals as the adoption process stopped at the level of discussions within Working Groups, such as the proposal for the e-card.

The proposal for a Directive on the Status of notifications is part of the same framework. The obligation for notifications of the Member States is based on the one hand in par. 7 of art. 15, which stipulates that Member States are required to notify the European Commission of the 
requirements imposed on access to or pursuit of a Service activity and which apply to their Service Providers established therein. It is also based on par. 5 of art. 39, which provides for the obligation to notify laws, regulations or administrative provisions containing requirements, which are imposed on the free provision of Services and which Member States intend to apply to cross-border Service Providers.

However, in January 2017, the European Commission presented a package of measures for the Services, including a Proposal for a Directive to improve the notification framework, as already provided for in Directive 123/2006. However, this Proposal for a Directive, due to strong concerns and reactions expressed during the trilogy (Council-Parliament-Commission) by many Member States, on important issues of the proposal, such as the nature of the European The obligation to notify the spatial plans, any administrative burden that may arise from the implementation of the Directive, did not proceed and the relevant discussions remained without result. In fact, from time to time, relevant compromise efforts have been made, which, however, have been fruitless.

To ensure the proper implementation of the Services Directive, several Member States have highlighted the need for more complete and specific guidance from the European Commission, through the provision of guidelines and up-to-date manuals for the Directive, meetings, and discussions at Member State level. members for an exchange of views and best practices. Regarding the issue of notifications, according to Articles 15 and 39 of the Services Directive, it should be noted that this issue, and in particular which requirements fall under the notification obligation, and which do not, is not yet clear to the Member States.

Today, 12 years after the entry into force of the Services Directive, although significant progress has been made in the cross-border provision of Services, but also in the establishment of providers in other Member States, we have not yet reached the stage where we consider that full and unfettered freedom to provide cross-border services (OECD, 2020). The reasons for this situation are many and varied. On the one hand, the Services Directive itself, although it is perhaps the most important piece of legislation for the Single Market and the legal basis for others later, is still in practice, in some ways, complex and possibly difficult and chaotic for implementers and in particular for the National Authorities of the Member States.

Furthermore, let us not forget that the Member States, and therefore the National Implementing Authorities, have a well-established mentality, specific needs and particularities as well as the structure and way of organizing and operating their administrative procedures, factors which are often practically difficult to bypass or require special time to adapt/change to the ever-changing global economic and social conditions.

In addition to the above, the very real conditions of the different economies and societies of the Member States of the European Union seem to be changing and evolving rapidly, which makes necessary the flexibility and adaptability of the existing system in the provision of Services. With the rapid transition to a Digital Transformation, but also the green economy, it turns out that the Services Directive is not and cannot be a sterile and outdated legislation but should follow the trends and easily adapt to current developments. 
Looking at the best economic conditions in the post-Covid-19 era, the deepening of the Single Market and the need to ensure and expand the freedom to provide services in the Member States of the European Union is further highlighted. The lesson has been hard enough for most Member States' economies from the adverse effect of coronary restrictive measures, both on the functioning of the European Single Market and on the Services sector.

To this end, it is necessary to update the relevant manual of the European Commission on the Services Directive, to include guidelines, in accordance with socio-economic developments, but also based on the modern case law of the Court of Justice of the European Union. The importance of continuous training of National Authorities by the European Commission should not be overlooked, through the provision of instructions, seminars and technical meetings, not only regarding the implementation of the Services Directive, but also the use of relevant tools of the Single Market, such as the Single Market Information System (IMI).

Equally important is the contribution of the Working Groups for the Implementation of the Services Directive, which should be continued on a more regular basis to identify the areas with the highest burden, but also the strategic areas with the largest addition, at EU level. and national level, value and to consider ways to ensure the smooth provision of Services as well as to reduce the administrative burden on the National Authorities.

Equally important is the contribution of the Working Groups for the Implementation of the Services Directive, which should be continued on a more regular basis in order to identify the areas with the highest burden, but also the strategic areas with the largest addition, at EU level. and national level, value and to consider ways to ensure the smooth provision of Services as well as to reduce the administrative burden on the National Authorities. It is a fact that the National Authorities (both in our country and in the other Member States) are confused about the issue of notification as, in many cases, they cannot understand the meaning, scope and content of the obligation as well as the way of fulfilling it. The relevant working groups of the European Commission are aware of the general ambiguity regarding this issue, as the European Commission cannot clarify which regulations are subject to this notification obligation.

It is noted that, for these regulations, many Member States, including our country, have expressed objections, concerns and concerns considering the large administrative burden, which is expected to arise from the implementation of this obligation. for these settings. For this reason, it is necessary to provide clear and comprehensible instructions from the European Commission, regarding the type of notifications, but also the relevant procedure through the Single Market Information System (IMI). It should be noted that the European Commission has informed that a manual is expected to be published, although the exact time of its publication is not yet known.

\section{Evaluation and Control of the Implementation}

In conclusion, in a general assessment, the Services Directive is rightly considered to be perhaps the most important piece of legislation in the Single Market, and substantial efforts have been made, not only for its fullest and most coherent integration into national legal 
systems, but and for its most effective practical application (Wiberg, 2014). However, it must not be forgotten that the Directive is not, and cannot be, a strict and obsolete text, but rather a living legal framework and an essentially useful tool, which incorporates and adapts the specificities of each Member State, as easily and comprehensively as possible, in the constantly changing social and economic requirements, needs and developments, both in the European Union and worldwide (Stelkens, Wein \& Mirschberger, 2012). A recent example is COVID-19 and the global negative impact on Trade in Services.

To investigate the progress of implementation, regulations and obstacles of the Services Directive, the European Commission has carried out three (3) evaluation studies in the years 2006, 2012 and 2017 under the title "Mapping and evaluation of the removal of legal and administrative barriers in the Services sector" (Eur. Commission, 2021, p.4).

The studies cover the 12 sectors of Services, such as Accounting and Tax Services, Architectural Services, Legal Services, Retail Services, Tour Guide Services, Tourist Services, Catering Services (Restaurants), Hotel Services, Construction / Building Services, General Construction Services: Services of Electricians and Plumbers, Services of Real Estate Agents and Wholesale Services.

\section{Development of barriers to Services over time, EU27}

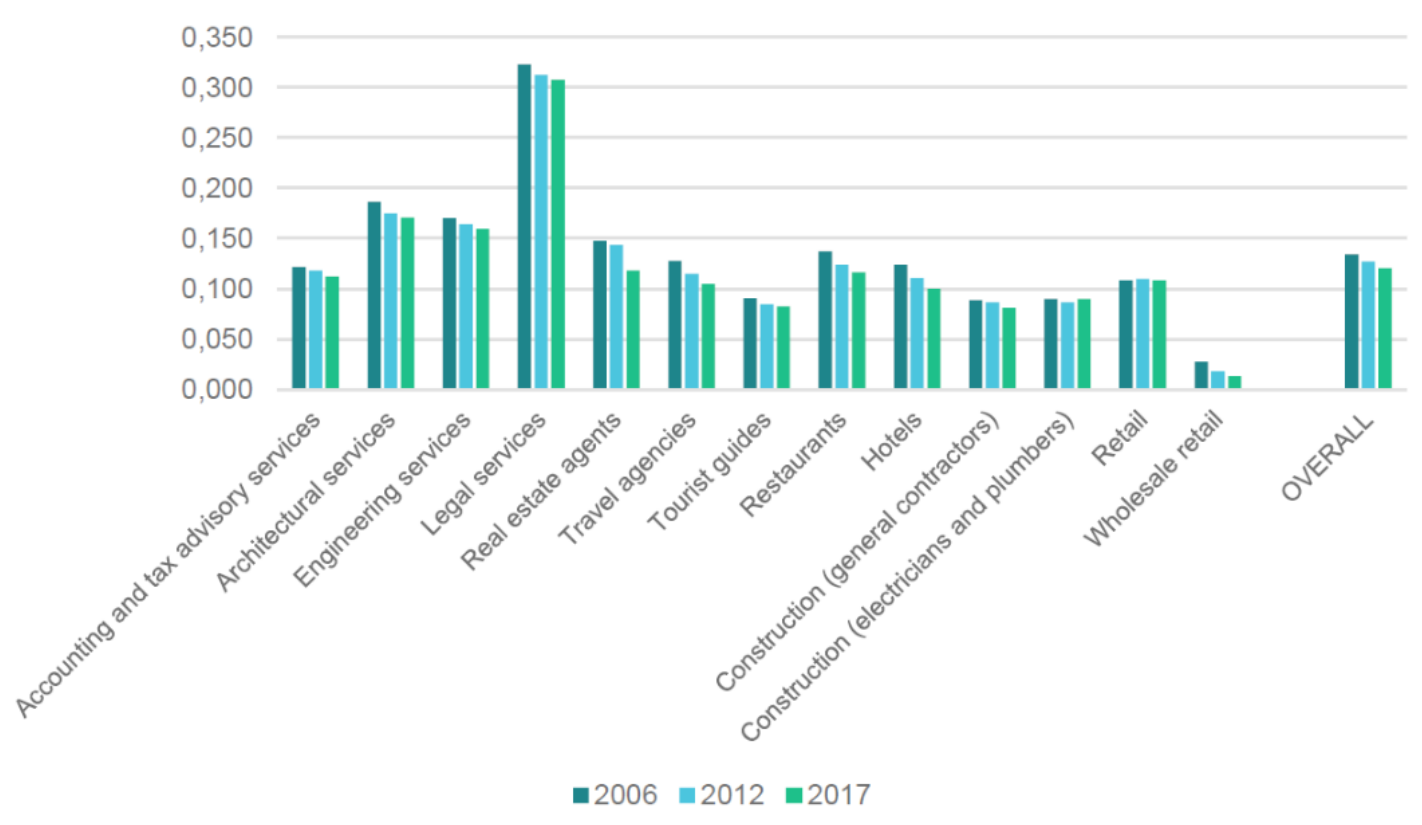

Source: EU Commission, Mapping Services, p. 14

The aim of the 2017 evaluation study was for the European Commission to form a broad view of developments in the regulation of Services markets and to obtain an overview of the remaining barriers as well as to understand how these barriers have evolved over time. The results of the study show how the obstacles to the implementation of the Services Directive evolve over time, but there is a slight decrease in their absolute level, in almost all areas of the sample. Also, the overall obstacle reduction speed is slow. For this reason, it is noted that it is necessary to continue and increase all reform efforts until the satisfactory implementation 


\section{Macrothink}

Journal of Public Administration and Governance ISSN 2161-7104 2022, Vol. 12, No. 1

of the Services Directive and the removal of regulatory and administrative barriers faced by Service Providers in the Single Market.

Finally, as mentioned above, the Services Directive excludes a significant number of individual Services (par. 2, art. 2). These Services were then covered by specialized Directives, and which were agreed upon in the following years. For convenience, a relevant report is provided for the following Services excluded in the Directive and the basic new specialized Directives:

Financial services (2002/65 / EC), such as those concerning banks (Directive 2014/59/EU).

Appropriations (COM/2018/0135).

Insurance (Document 32009L0138) and Reinsurance (Directive 2009/138/EC).

Occupational or Personal Pensions (Directive 2019/1158).

Securities Directive (2019/2162).

Investments (Directive 2011/61/EU).

Funds (Directives 73/239/EEC and 92/49 /EEC).

Payments (Directive 2011/7/EU).

Investment Advice (Document 52011PC0656), including services listed in Annex I to Directive 2006/48/EC.

Electronic Communications Networks (Directive 2014/61/EU), as well as related facilities and services (Regulation 2017/352 / EU) and issues regulated by Directives 2002/19/EC, 2002/20/EC, 2002/21/EC, 2002/22/EC and 2002/58/EC.

> Transport (Directive 2019/520/EU), including port services (EU Regulation 2020/697), which fall within the scope of Title V of the Treaty.

Temporary employment agencies (Document 32006L0123)

Health Care Services (Directive 2011/24/EU) whether they are provided through healthcare facilities and regardless of how these services are organized and funded nationally or whether they are public or private.

Audiovisual services (Directive 2010/13/EU), including cinematographic services (Directive 2006/123/EC), irrespective of the way they are produced, distributed, or broadcast, and on radio broadcasts.

$>$ Gambling Services (COM (2011) 128, Doc. 52011DC0128) in which the player bets monetary value, including lotteries, casino gambling and betting transactions.

Private security services (COM/2013/048, Document 52013PC0048). 
Services of Notaries (Directive 2006/123/EC, Document 32006L0123) and the bailiffs (1393/2007/EC), appointed by an official act of the Administration.

\section{Conclusions}

In recent decades, the Services sector has been the backbone of the global economy and the most dynamic player in international trade. Trade in Services accounts for $\tau \alpha$ AE GDP of developed countries and is growing dramatically in developing countries. The development of technology (digitization) significantly facilitates cross-border trade and opens new opportunities and possibilities for traders and consumers, whose countries are geographically far apart. The internationalization of Trade in Services increases economic and trade cooperation and overcomes obstacles to free trade.

Trade in Services helps to develop countries' economies, increases competition, and promotes the personal skills of employees. It also helps protect the consumer and the general well-being of citizens, increasing jobs and helping to reduce social inequalities. The movement of employees to other countries of production of the Services of companies (mode 4) expands their professional horizons and is an incentive to improve and develop the professional and educational skills of young, especially older, employees.

Services today are distinguished by complexity as they are now mixed with the production of goods, trade and consumption despite their clearly defined differences and the special characteristics of the Services. The existence and application of international standards and rules of marketing and development in all sectors of the Services could facilitate the flow of information and cooperation that would increase world trade and improve international trade relations. The international economic and commercial environment is constantly changing, state business aid in all sectors is increasing, overtly or covertly, and commercial copyright is being violated through uncontrolled copying and falsification.

For all the above reasons, the existence of the World Trade Organization, as well as other International Economic Organizations, is considered necessary. The statutory purpose of the World Trade Organization is the liberalization and free flow of world trade (goods, services, copyrights, government procurement, trade facilitation), through a system of rules aimed at unimpeded economic and trade cooperation between the 254 Member States and observer countries of the Agency.

The European Single Market is a cornerstone of Europe, a single space in which Citizens, Goods, Services, and Capital move freely and unhindered. A fully functioning Single Market allows EU citizens to enjoy a wider range of services and products as well as better employment opportunities. Equally important, however, are its benefits for companies wishing to develop cross-border activity.

For this reason, the institutions of the European Union support any initiative to restore, further deepen and strengthen the Single Market, but also to ensure its resilience. To date, the creation of a functional, at least, Single Market is hampered by various factors, such as: 


\section{Macrothink}

Journal of Public Administration and Governance

ISSN 2161-7104

2022, Vol. 12, No. 1

a) Remaining obstacles and unjustified barriers. These are mainly caused by incorrect application and enforcement of EU law in the Member States. The European Commission is making continuous efforts to map out and consequently eliminate these legal, administrative, bureaucratic, and other barriers.

b) Endogenous factors, as for example internal changes and developments within the Single Market. The legislation itself needs to be updated in such a way as to meet the new needs, but also in line with the constantly changing economic and climate goals.

c) Exogenous factors, as the pandemic Covid-19. Despite significant efforts to stimulate EA, the Covid-19 pandemic has demonstrated significant weaknesses, causing significant severe damage in many areas, in particular the free movement of services and goods.

The Services Directive is the most important step towards achieving a Single Market as it ensures that both service providers and recipients of services can more easily benefit from fundamental freedoms of the European Union, such as freedom of establishment and freedom to provide services to cross-border level. In this regard, its provisions aim at simplifying administrative procedures, removing obstacles to the provision of Services, and strengthening both mutual trust between Member States and the trust of providers and consumers in the Internal Market (Implementation Manual). for Services).

Today, despite significant progress in the provision of cross-border services, as well as in the establishment of providers in other Member States, we do not have the European Single Market in Services far from the expected full and unfettered freedom of cross-border services. The main reason is that the Services Directive is still, in practice, complex and potentially difficult and chaotic for its implementers, and in particular for the National Authorities of the Member States of the European Union. For this reason, it is deemed necessary to update the relevant manual for the Services Directive, so that it includes comprehensible guidelines, in line with socio-economic developments, but also based on the modern case law of the Court of Justice of the European Union.

The Services Directive is one of the most important legislations of the European Union as all the Directives of the individual forms and sectors of the Services are based on its general principles. The Directive applies to a wide range of service activities, and its provisions are largely based on the case law of the Court of Justice of the European Union, which supplements, delimits or clarifies them. With the implementation of the Services Directive, Member States are called upon to take additional legislative measures to meet these conditions. Finally, a number of individual Service Directives and Regulations have been agreed in the European Union and are still being negotiated.

\section{References}

Adlung, R., \& Mamdouh, H. (2014). How to design trade agreements in services: Top down or bottom-up?. Journal of World Trade, 48(2). https://doi.org/10.2139/ssrn.2283168

Antimiani, A., \& Cernat, L. (2018). Liberalizing Global Trade in Mode 5 Services: How 


\section{Macrothink}

Journal of Public Administration and Governance ISSN 2161-7104 2022, Vol. 12, No. 1

Much Is It Worth?. Journal of World Trade, 52(1), 65-83. Retrieved from https://kluwerlawonline.com/journalarticle/Journal+of+World+Trade/52.1/TRAD2018004

Barnard, C. (2008). Unravelling the services Directive. Common Market Law Review, 45(2), 323 - 394. Retrieved from

https://kluwerlawonline.com/journalarticle/Common+Market+Law+Review/45.2/COLA2008 $\underline{026}$

Bublitz, E. (2018). The European Single Market at 25", Intereconomics, 53(6), 337-342. http://dx.doi.org/10.1007/s10272-018-0779-7

Cernat, L. (2017). Trade, Technology and Mode 5 Services: What is at Stake for Developing Countries? UNCTAD, Geneva, 18-20 July 2017. Retrieved from https://unctad.org/system/files/non-official-document/c1mem5_2017_108_S2_Cernat.pdf

Chang, M. (2010). The Services Directive: Trojan Horse or White Knight?. Journal of European Integration, 32(1), 97-114. https://doi.org/10.1080/07036330903375206

Corugedo Fernández, E., \& Ruiz Pérez, E. (2014). The EU Services Directive: Gains from Further Liberalization. IMF WP/14/113, 3-23. https://doi.org/10.5089/9781498391726.001

Delgado, J. (2006). The European Services Directive. The Brookings Institution, Center on the United States and Europe, 1-6. Retrieved from http://www.brookings.edu/fp/cuse/analysis/index.htm

Erixon, F., \& Georgieva, R. (2016). What is Wrong with the Single Market? The Five Freedoms Project. European Centre for International Political Economy, Working paper, No 1, 1-24. Retrieved from https://ecipe.org/wp-content/uploads/2016/04/PR-F5-0215.pdf

European Commission. Services Directive in practice, Implementation of the Services Directive. Retrieved from https://ec.europa.eu/growth/single-market/single-market-services/services-directive/practice/i mplementation_el

European Commission. Single market for Services. Retrieved from https://ec.europa.eu/growth/single-market/single-market-services_en

European Commission. Directorate-General Internal Market and Services (MARKT) Retrieved from https://www.eumonitor.eu/9353000/1/j9vvik7m1c3gyxp/vg9ib57zgayj

European Commission (2021). Mapping and assessment of legal and administrative barriers in the services sector. Directorate-General for Internal Market, Industry, Entrepreneurship and SMEs (DG GROW), Unit D1, pp. 1-13 Retrieved from https://op.europa.eu/en/publication-detail/-/publication/6d8d8858-a756-11eb-9585-01aa75ed 71a1/language-en

Feijóo Núñez, A. (2019). Transposition of the Services Directive and subsidiarity: A view from Galicia. European View, 18(1), 37-44. https://doi.org/10.1177/1781685819843206

Foltea, A. (2018). How to include 'Mode 5' services commitments in bilateral free trade 
agreements and at multilateral stage?. European Parliament, Policy Department for External Relations. EP/EXPO/B/INTA/2018/02

Gao, H. (2018). The WTO Dispute Settlement Mechanism: A Trade Court for the World. RTA Exchange. Geneva: International Centre for Trade and Sustainable Development (ICTSD) and the Inter-American Development Bank (IDB). Retrieved from www.rtaexchange.org/

Garabiol-Furet, M-D. (2006). The Services Directive: moving towards a consensus. Fondation Robert Schuman, European Issue $n^{\circ} 17$. Retrieved from https://www.robert-schuman.eu/en/european-issues/0017-the-services-directive-moving-towa rds-a-consensus

Klamert, M. (2014). Services Liberalization in the EU and the WTO Concepts, Standards and Regulatory Approaches. Cambridge University Press, Chapter 6, 174-222. https://doi.org/10.1017/CBO9781139540810

Kox, H., \& Lejour, A. (2006). The Effects of the Services Directive on Intra-eu Trade and fdi. Revue économique, 57, 747-769. https://doi.org/10.3917/reco.574.0747

Ministry of Foreign Affairs (2021). Single Market and Relevant Policies. Retrieved from https://www.mfa.gr/en/foreign-policy/greece-in-the-eu/internal-market.html

Nordwall, A. (2016). The Servicification of EU Manufacturing. October, National Board of Trade Sweden. ISBN: 978-91-88201-17-1

OECD (2020). Committee on Financial Markets (2020). Cross-Border Trade in Financial Services: Economics and Regulation. Financial Market Trends, 75, 23-60. https://www.oecd.org/finance/financial-markets/1923208.pdf

OECD (2009). The Implementation of the Service Directive. Retrieved from https://www.oecd.org/gov/digital-government/implementationoftheeuservicedirective.htm

Parasuraman, A., Zeithaml, V. A., \& Berry, L. L. (1988). SERVQUAL: a multiple-item scale for measuring consumer perceptions of service quality. Journal of Retailing, 64(1), 2-40.

Schrijvershof, D., \& Martijn van de Hel (2019). The Services Directive. Retrieved from https://www.maverick-law.com/en/blogs/the-services-directive.html

Stelkens, U., Weiß, W., \& Mirschberger, M. (2012). The Implementation of the EU Services Directive: Transposition, Problems and Strategies. https://doi.org/10.1007/978-90-6704-840-8

Szczepanski, M. (2013). Further steps to complete the Single Market. Library Briefing, Library of the European Parliament.

UNCTAD (2020). Handbook of Statistics 2020. International Trade in Services. Retrieved from https://unctad.org/webflyer/handbook-statistics-2020

Wiberg, M. (2014). The EU Services Directive: Law or Simply Policy? Springer https://doi.org/10.1007/978-94-6265-023-7 


\section{Macrothink}

Journal of Public Administration and Governance ISSN 2161-7104 2022, Vol. 12, No. 1

WTO (2019). World Trade Report 2019: The Future of Services Trade. Geneva. Retrieved from https://www.wto.org/english/res_e/publications_e/wtr19_e.htm

WTO (2020). Trade in Services in the context of Covid-19. Information Note, Geneva. Retrieved from https://www.wto.org/english/tratop_e/covid19_e/services_report_e.pdf

Zeithaml, V. A. (1988). Consumer perceptions of price, quality, and value: A means -end model and synthesis of evidence. Journal of Marketing, 52(3), 2-22. https://doi.org/10.1177/002224298805200302

\section{Copyright Disclaimer}

Copyright for this article is retained by the author(s), with first publication rights granted to the journal.

This is an open-access article distributed under the terms and conditions of the Creative Commons Attribution license (http://creativecommons.org/licenses/by/4.0/). 